\title{
Просветительская деятельность епископа Лаврентия (Горки) на Вятской земле
}

\author{
Помелов В. Б., \\ ФГБОУ ВО «Вятский государственный университет», кафедра педагогики \\ Kirów, Rosja \\ lena_bigstar@mail.ru

\section{Сахарова Л.Г.,} \\ ФГБОУ ВО Кировский ГМУ Минздрава РФ, кафедра гуманитарных и социальных наук \\ кандидат исторических наук, доцент, заведующая кафедрой гуманитарных и социальных наук \\ Kirów, Rosja \\ slg75@rambler.ru
}

\section{Сахаров B.A.}

ФГБОУ ВО «Вятский государственный университет», кафедра педагогики

Kirów, Rosja

vas701@rambler.ru

Pomelov V. B., Sakharova L.G., Sakharov V.A., The enlightment activities of Bishop Lawrence (Gorka) on the Vyatka land, Elpis, 19 2017: 127-131.

Pomelov V. B., Sakharova L.G., Sakharov V.A., Działalność oświatowa biskupa Laurencjusza (Gorki) na Wiackiej ziemi, Elpis, 19 2017: 127-131.

Аннотация: В статье раскрывается содержание просветительской деятельности епископа Лаврентия Горки, создателя первой
школы на Вятской Земле; показаны социально-политические условия, в которых проходил этот начальный этап просвещения.

Abstract: In the article the educational activities of the bishop Lavrenty Gorka, the founder of the first school in the Vyatka region, are described. The socio-political conditions, which influenced the initial stage of the process of the enlightenment, are shown.

Streszczenie: W artykule skupiono się nad edukacyjną działalnością biskupa Laurencjusza Gorki, twórcy pierwszej szkoły na Wiackiej ziemi. Opracowanie ukazuje również społeczno-polityczne uwarunkowania, w których odbywał się początkowy etap edukacji.

Ключевые слова: Вятская Земля, император Петр I, императрица Анна Иоанновна, Лаврентий Горка, Феофан Прокопович, М.Е. Финицкий, Василий Лещинский, Иоаким Богомедлевский, Вятская славяно-латинская школа

Keywords: Vyatka region, the Emperor Peter the First, the Empress Anna Iohannovna, Lavrenty Gorka, M.E. Finizky, Vasily Leschshinsky, Ioakim Bogomedlevsky, the Vyatka Slavonic-Latin school

Słowa kluczowe: Wiacka ziemia, cesarz Piotr I, cesarzowa Anna Iwanowna, Laurencjusz Gorka, Teofan Prokopowicz, M. E. Finicki, Wasyl Leszczyński, Joachim Bogomiedliewski, Wiacka szkoła słowiańsko-łacińska

Первые шаги по развитию государственного просвещения в России традиционно связываются с деятельностью императора Петра I в первой четверти XVIII в. Временем были востребованы духовные проповедники другого склада мыслей и образа действий, а именно яростные поборники петровских преобразований, настоящие борцы за дело просвещения. Таковым в историю Вятского края вошел епископ Вятский и Великопермский Лаврентий I (Горка), деятельность которого дала мощный толчок к развитию просвещения на Вятской Земле. Краткая по времени (1733-1737), но очень плодотворная его деятельность «на Вятке» оставила заметный след в местной истории. Именно с созданной им здесь школы ведет свой отсчет просвещение в этом крае.
Лаврентий (в миру - Андрей) Горка родился в 1671 г. в небольшом городке Лавров, близ г. Львова. По окончании Киево-Могилянской духовной академии, одного из крупнейших учебных заведений России того времени, он преподавал в нем вместе со своим другом Феофаном Прокоповичем (1681-1736), вел курс «пиитики» (с 1706 г.) и риторики (1708-1710 гг.). В 1710 г. Горку за отличие по службе утвердили игуменом Выдубицкого монастыря в Киеве. В 1722 г. он стал архимандритом Воскресенского монастыря на Истре. В тот же год Горка был приглашен в Санкт-Петербург и назначен обер-иеромонахом армии и флота. За свою ученость и усердие Горка заслужил особенное благоволение императора и 8 сентября 1723 г. был назначен епископом в Астрахань, где служил до 1727 г. Далее 
он служил епископом в Великом Устюге (1727-1731), Рязани (1731-1733) и, наконец, в Хлынове (1733-1737), - главном городе Вятской земли.

Торжественная встреча нового вятского епископа произошла 9 сентября в церкви Всех Святых. Хлыновцы были удивлены скорым приездом Лаврентия, последовавшим на пятый день после отъезда епископа Алексия. Лаврентий был архиереем совсем другого типа по сравнению со своими предшественниками. «Привыкшие к важным, тихим, размеренным движениям и речам старо-русских предместников, хлыновцы увидели перед собой характерного малоросса, были изумлены его подвижностью, необыкновенной живостью его речей и жестов» $[5$, с. 56$]$.

В ходе подготовки к открытию школы, первой в Вятском крае и в Предуралье, Горке пришлось столкнуться со многими трудностями (отсутствие учебных пособий, учительских кадров, средств, помещений и т. п.). Но самым большим препятствием было активное сопротивление со стороны части местного духовенства, закосневшего в невежестве и не желавшего получать в лице учащихся будущих конкурентов на занятие «лучших священнических мест». Епископу пришлось отрешать от должности священнослужителей, мешавших работе школы, причем в ряде случаев меру наказания определял Святейший Синод, к помощи которого Лаврентий Горка был вынужден прибегать. Важным направлением деятельности епископа Лаврентия было «выправление» хозяйственного положения архиерейского дома, которое ко времени приезда Л. Горки в город Хлынов в 1733 г. было плачевным. От предшественника не осталось не только домовой денежной казны, но был долг в коллегию экономии в размере 529 p. 34 к. [1, с. 13]. Тем не менее, епископ незамедлительно приступил к созданию школы. Он требовал, чтобы все монастыри доставили в архиерейский дом двадцатую долю хлеба. Однако ни одно распоряжение епископа не было принято к исполнению быстро и охотно.

Непростыми были и поиски «годного для обучения студентов человека к себе на Вятку». Найти учителей оказалось делом нелегким. Киевские богословы неохотно отзывались на приглашения архиереев занимать должности в провинциальных школах. Между тем, Л. Горка в своем стремлении совершенствовать организацию обучения устанавливал культурные и научные связи с известными центрами просвещения и развития педагогической мысли. С этой целью он пишет письмо в свою «альма матер» - Киево-Могилянскую духовную академию с просьбой направить в Хлынов учителей. Ему удалось пригласить в Хлынов студента класса философии Михаила Евстафьевича Финицкого, который согласился приехать в Хлынов, когда получил согласие Л. Горки на свои условия - годовое жалованье в 72 p. [4, c. 315]. Финицкий приехал в Хлынов в апреле 1734 г. Именно его можно с полным основанием считать первым учителем на Вятской земле, а Лаврентия Горку - первым просветителем, первым организатором просвещения.
В тот же год появился и второй учитель из студентов Киево-Могилянской духовной академии - Василий Лещинский. Третьим учителем школы стал ученый иеромонах Иоаким Богомедлевский, обучавшийся в молодости в шести европейских университетах. Первые учителя Вятской школы имели достаточно высокое для того времени образование, были гуманными и доброжелательными по отношению к детям наставниками. В школе были исключены физические наказания.

Особую заботу Л. Горка проявлял о приобретении книг. Он составил реестр «книг латинских», которые закупались в Москве, Санкт-Петербурге, Киеве, Астрахани, Рязани, Великом Устюге. В школьной библиотеке имелись произведения Гомера, Данте, Цицерона, Сенеки, Горация, Овидия, Петрония, Вергилия и других классических авторов, а также лучшие для того времени учебные пособия, например, учебники Эммануэля Альвара по началам латинского языка, так называемые «Альваровы рудименты».

Обязательное открытие при школах библиотек особо оговаривалось в «Духовном регламенте». Согласно одному из его положений, пользоваться книгами преподаватели и ученики должны были в специальной «библиотечной конторе». Предусматривалась также выдача книг на дом. Вводилась регламентация работы библиотек. Для архиерейских школ по всем епархиям было разослано 900 букварей и 920 грамматик, которые положили начало школьным библиотекам. Л. Горка отдал в школу все книги богатейшей для того времени своей личной библиотеки.

Составленная после смерти Л. Горки опись его библиотеки включала 355 книг, причем две трети из них были на иностранных языках: на латинском, греческом, еврейском, польском [10, с. 292-293]. Некоторые рукописи из библиотеки школы, (впоследствии ставшей духовной семинарией), созданные преподавателями и учащимися сохранены и поныне [6, с. 144]. В семинарской библиотеке хранились стихотворные посвящения учеников важным событиям и отдельным лицам. Оригинальные произведения содержит ученическая тетрадь Агафона Свешникова - будущего протоиерея Спасского собора, относящаяся к середине XVIII в. [8, c. 265]. Лучшая часть библиотеки семинарии, «за особливой их редкостию», была передана в 1741 г. в распоряжение Синода по его настоятельному требованию [2, c. 30]. В Хлыновской школе остались, по данным описи 1739 г., 34 книги, а по другим данным - 42, переданные Горкой еще при жизни в школьную библиотеку [8, с. 278]. Даже после смерти Л. Горки в семинарию продолжали некоторое время приходить выписанные им «на суммы архиерейского дома» сочинения на латинском языке.

Теперь, когда задачи хозяйственного обеспечения работы школы, подбор учителей, приобретение книг были, в основном, завершены, дело стало за набором учащихся из детей «лучшего священства», многие из которых стремились в массе своей избежать учения. Духовенство считало отправку детей в школу своей 
самой тяжелой повинностью. Л. Горкой было сделано распоряжение о «наборе робят» в архиерейский дом для помещения их в латинскую школу. Он потребовал, чтобы все священнослужители привели к нему своих детей, начиная с семилетнего возраста «без малейшего замедления», под «опасением» самой строгой ответственности в случае утайки детей или медленного исполнения архиерейского указа. «Духовным регламентом» и новым указом Анны Иоанновны (1731) архиереям предлагалось брать в школы и детей «лучших градских детей», а «тех, которые из них в школе быть не похотят, имать в школы и неволею» [1, с. 14]. Поэтому Л. Горка сделал распоряжение о наборе в школу детей лиц гражданского ведомства и даже военных, находившихся тогда в ведении духовной власти. Однако поначалу всего несколько священнослужителей, и то из близлежащих к Хлынову монастырей, привели своих детей учиться; «остальные всеми возможными случаями старались укрыться от школы» [15, с. 107].

К началу 1735 г. удалось собрать до четырехсот учеников в возрасте от 7 до 25 лет. Но Л. Горка действовал не только кнутом, но и пряником. Он «побуждал духовых, в надежде лучшего священства», то есть, обещая назначения в более богатые приходы, отдавать в школу своих детей, обязывая в назначенные сроки предварительно обучить их на дому пению, чтению и письму, «под опасением лишать непослушных священства и чинов» $[11$, c. 30]. Однако самовольные побеги детей из школы не были редкостью. Таким образом, используя методы принуждения и поощрения, Л. Горке удалось, несмотря на сильнейшее противодействие, в 1734 г. открыть школу. По отношению к учащимся своей школы Горка проявлял гуманность. Тем не менее, условия содержания нельзя было признать благоприятными: дети проживали в холодных монастырских кельях, скудно питались, и поэтому нередко убегали домой. За «утеклецами» снаряжалась погоня. Дети «недостаточных» родителей, не имевшие родственников в Хлынове, помещались на готовое содержание и получали питание, одежду и книги бесплатно. Но большая часть учеников была на содержании родителей, и посещала школу только на время уроков.

Л. Горка уделял большое внимание рациональной организации работы школы, взяв при этом за образец свою «альма матер» - Киево-Могилянскую духовную академию. Это проявилось, прежде всего, в выборе предметов для обучения и особенностях построения учебного процесса. После того как в первый учебный год «профессор» Финицкий обучил учащихся «верхней школы» «Алваровым рудиментам», а «инспектор нижней школы» Лещинской с начинающими учениками одолел основы славянской грамоты, Горка уже со второго года работы школы выделил шесть классов, получивших названия по основному учебному предмету (фара, инфима, грамматика, синтаксима, пиитика, риторика). Разумеется, различие между рассматриваемыми двумя учебными заведениями, одно из которых было школой в предуральском захолустье, а другое - учреждением российского масштаба, далеко не ограничивалось лишь отсутствием в вятской школе, в сравнении с Киевской академией, двух старших классов (философии и богословия), однако само стремление Л. Горки ориентироваться на лучшие образцы при устройстве учебного заведения, способствовало укреплению авторитета его школы, повышению качества обучения в ней и, несомненно, было одной из важнейших сторон его просветительской деятельности на Вятской земле.

Обладая жестким характером, Л. Горка проводил, подобно Петру I, «варварскими методами борьбу против варварства», чем вызывал недовольство среди местного духовенства. Однако его деятельность, конечно, носила прогрессивный характер, за что он и получил впоследствии в народе почетное звание «просветителя Земли Вятской». Заложенный Л. Горкой интерес к чтению среди вятчан выразился, например, в том, что спустя несколько лет после его смерти и восстановления пришедшей было в упадок школы, за границей было выписано для семинарии книг «избранных церковных и лучших классических писателей» на 1500 рублей. Система образования и воспитания в школе Л. Горки закладывала в учениках понимание литературных ценностей, формировала вкус к творческим опытам. Учащимися переписывались и переводились с других языков отдельные учебные пособия, создавались даже оригинальные произведения, чему в значительной степени способствовали поддерживавшиеся в этом учебном заведении на протяжении всего периода его существования традиции стихотворчества и «лицедейства». Стремясь доставить детям «приличные развлечения», Л. Горка позволял им в определенные дни и часы развлекаться играми, как в самом архиерейском доме, так и во время прогулок за городом. В зимнее время, особенно перед праздниками, в школе разыгрывались духовные мистерии. Ученики школы участвовали в торжественных церковных процессиях. Воспитанники «разыгрывали действа»; в репертуар входила и трагикомедия самого Горки - «Иосиф». Традиции «школьной драмы» (то есть драматизации) были продолжены и после его смерти в стенах Вятской духовной семинарии $[13$, с. 30$]$.

Основатель Хлыновской славяно-латинской школы епископ Л. Горка и его соратники и последователи были, как показывает анализ их деятельности на Вятской земле, несомненно образованными и талантливыми людьми, стремившимися служить народу на ниве просвещения. Первый «фундатор» школы, по всей вероятности, был ознакомлен с лучшими достижениями педагогической практики европейских стран, в частности с классно-урочной системой, которая, как известно, получив известность после Я. А. Коменского, вела, тем не менее, свое начало от братских школ Украины и Польши, то есть именно там, где прошла значительная часть жизни вятского просветителя.

Основным учебником во всех четырех классах был учебник Эммануэля Альвара, перешедший в Киев из Западной Европы еще в XVII в., а затем и в русские 
школы. В России он неоднократно переиздавался, несмотря на то, что, по мнению историка П. Пекарского, «из всех учебников латинского языка грамматика Альвара была, может быть, самым темнейшим, так, что была непонятна не только для начинающих изучать латынь, но даже и для тех, кто знал ее порядочно» [12, c. 242].

Умение составлять предики очень ценил Л. Горка. Он был первым проповедником в Хлынове, который сам составлял устные проповеди. Даже самая простая проповедь считалась в то время слабой и «не изящной», если в ней не было «мифологических применений». Не всегда простым, неграмотным жителям Хлынова, приходившим в храмы, были понятны «предики» первых проповедников. Но это был первый опыт живой устной речи, свободного обращения к большой массе народа. Вслед за наставлениями в умении составления и «апробации» живой проповеди упражнялись и учащиеся. М. Е. Финицкий отмечает: «В школах мною основанных, некоторые из студентов в толикую моими трудами произошли науку, что во всю покойного преосвященного Вениамина бытность поучения в церквах сказывали, також уже и в бытность вашего преосвященства, какового суть оныя учения, в самоперсональном проповедения их слушании ваше преосвященство аппробовать их изволил» [7, с. 97]. Риторикой заключался круг наук, которым обучали в Хлыновской школе. Класс риторики был открыт в 1738 г. Некоторые школьники оставались в нем по несколько лет и, «выслушав», таким образом, полный курс школы, жаловались, что «за непроизведением в школе высших наук» быть им в реторике вельми стало скучно, и в оной школе они всуе содержатся, и токмо лета теряют напрасно» [3, с. 199].

10 апреля 1737 г. был праздник Святой Пасхи. По окончании обедни все власти города Хлынова поспешили в архиерейский дом принести поздравления преосвященному Владыке. Но у дверей дома они были остановлены двумя верными слугами епископа - калмыками Титом и Романом, обращенными в христианство в бытность служения Лаврентия в Астрахани и последовавшими за своим господином в Хлынов. Они объявили, что «Владыка почивает» и не следует его беспокоить. Вечером того же дня, по окончании радостного пасхального звона во всех храмах города, печальные звуки соборного колокола известили горожан о том, что их архипастырь «почил тем непробудным сном, от которого возбудит его только труба архангела Михаила» [2, с. 31].

Несколько человек, в их числе духовник Владыки архимандрит Лаврентий Полторацкий, Финицкий и Лещинский, а также два келейника были свидетелями кончины Л. Горки, последовавшей в седьмом часу вечера. Первый вятский просветитель Лаврентий Горка был похоронен в Вятском кафедральном соборе, на северной стороне, в холодном храме. В надписи на гробнице, устроенной в 1772 г., он назывался «ревностным по Бозе Иерархом, бодрым словесных овец пастырем, мудрости и благочестия любителем, крайним невежества и суеверия ненавистником». Здесь же спустя столетие были выбиты вдохновенные строки, - дань памяти первому просветителю на Вятской земле:

«Всеобщий смертный рок в сём месте мужа скрыл, Который первый здесь науки насадил, -

Хотя Всевышня Власть, что целым светом правит,

Ему и не дала конечно их возставить.

Лаврентий Горка сё! А кто он был таков?

Епископ вятский, муз любитель, богослов» [14, с. 49-50].

Большинство хлыновского духовенства полагало, что школа - затея «поляка-архиерея» со смертью «затейщика» «покончится». И действительно, первые два месяца после смерти Л. Горки были временем ее полной дезорганизации. Однако уже в середине июня 1737 г. был получен указ Святейшего синода с требованием «содержать школы как было при жизни преосвященного Лаврентия во всем неотменно» [14, с. 81].

Подвижническая жизнь Горки стала предметом специального изучения со стороны вятских историков, начиная со второй половины ХІХ в. Писатель Н.С. Лесков в своем сатирическом произведении «Святительские тени» дал описание деятельности вятских епископов VIII в. Будучи в этом вопросе человеком совершенно беспристрастным, он уничтожающими эпитетами («бонвиваны», «бражники», «скопидомы», «невежи» и т. п.) охарактеризовал всех вятских «архипастырей», за исключением Л. Горки, которого он признал достойным своего сана [9]. В исключительно яркой и самобытной личности Лаврентия Горки с особенной силой привлекают его несгибаемая воля и настойчивость, огромная эрудиция и значительный литературный талант, стремление даже ценой собственной жизни развеять вековую тьму невежества, помочь народу в преодолении извечного российского отставания в области просвещения [15]. До настоящего времени для вятского учительства Л. Горка выступает своего рода нравственным ориентиром. Его имя считается символом просветительства, беззаветного служения просвещению народа. Несмотря на свое непродолжительное пребывание «на Вятке», Л. Горка оставил по себе добрую, прошедшую сквозь века память. 


\section{Литература}

1. Верещагин А.С. История Вятской духовной семинарии // Вятские епархиальные ведомости. - 1868, № 1. - С. 4-19.

2. Верещагин А.С. История Вятской духовной семинарии // Вятские епархиальные ведомости. - 1868. № 2. - С. 24-32.

3. Верещагин А.С. История Вятской духовной семинарии // Вятские епархиальные ведомости. - 1868. № 12. С. 197-204.

4. Верещагин А.С. Ученый южнорусс на Вятке в XVIII в. // Памятная книжка и календарь Вятской губернии на 1895 г. Отдел IV. - Вятка, 1894. - С. 302-321.

5. Верещагин А. С. Эпизоды из жизни основателя Вятской семинарии. Эпизод V. Архиерейство на Вятке // Памятная книжка и календарь Вятской губернии на 1902 г. Вятка, 1901. - С. 50-102.

6. Вятский архиерейский дом и архиерейские вотчины 1827 г. // Труды Вятской ученой архивной комиссии. Выпуски 1-2, отдел 3. - Вятка, 1916. - С. 140-144.

7. Два прошения М.Е. Финицкого преосвященному Варлааму Скамницкому. 1743 и 1745 гг. // Труды Вятской ученой архивной комиссии. Выпуск 3. Отдел 3. - Вятка, 1905. - С. 95-97.

8. Кудрявцев И.М., Шлихтер Б.А., Щапов Я.Н. Археографические экспедиции отдела рукописей Государственной библиотеки имени В. И. Ленина в 1953-1956 г2. M., 1956. - С. 256-301.

9. Лесков Н.С. Святительские тени // Исторический вестник. - 1881, № 5. - С. 53-69.
10. Луппов С.П. Книга в России в послепетровское врмя. 1725-1740. - Л., 1976. - 420 с.

11. Никитников Г.А. Иерархия Вятской епархии. - Вятка, 1863. $-214 \mathrm{c}$.

12. Пекарский П. История науки и литературы в России при императоре Петре Великом: в 2 т. - Т. 1. - СПб., 1862. $-420 \mathrm{c}$.

13. Поздеев В.А. Лаврентий Горка // Энциклопедия Земли Вятской: в 10 т. Т. 2. Литература. - Киров, 1995. - С. 29-30 .

14. Помелов В.Б. Просветительская деятельность русской православной иеркви (начало-вторая треть XVIII в. // Религии народов Вятского края: Учебно-справочное пособие /отв. ред. А.Г. Поляков. - Киров, 2009. - С. 37-62.

15. Помелов В. Б. Насилие гуманизм в деятельности первого вятского просветителя Лаврентия Горки // Традиции и новации в педагогике ненасилия: материалы всероссийской научной конференции / под ред. В. С. Данюшенкова и В. А. Ситарова. - Киров, 1996. - С. 79-81.

16. Помелов В.Б. Просветительство русской православной иеркви в российской провинции на примере Вятского края: монография. - Саарбрюккен, 2013. - 352 с. Помелов В.Б. Вятский просветитель Лаврентий Горка // Педагогика. - 2009, №2. - С. 75-83. Помелов В.Б. Выдающийся просветитель Вятской земли епископ Лаврентий Горка // Историко-педагогический журнал. - 2017, №1. - C. 79-94. 
ISSN 1508-7719

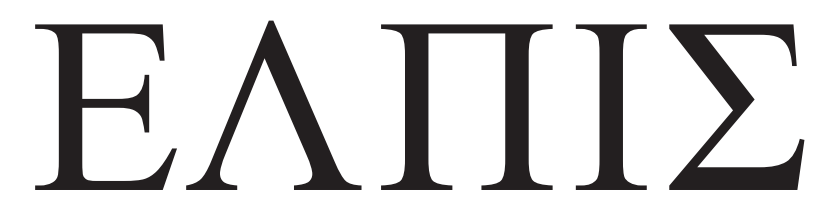

CZASOPISMO TEOLOGICZNE KATEDRY TEOLOGII PRAWOSŁAWNEJ UNIWERSYTETU W BIAŁYMSTOKU

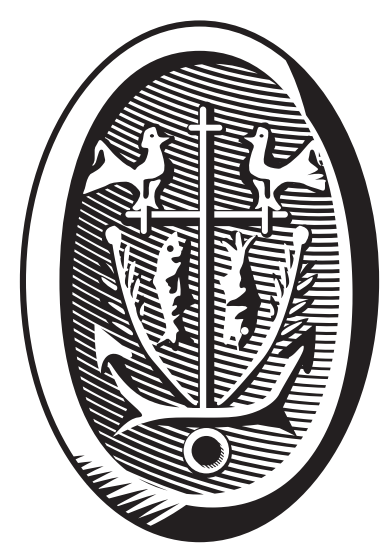

ADRES REDAKCJI

15-097 Białystok, ul. M. Skłodowskiej-Curie 14 tel. 85 745-77-80, e-mail: redakcja@elpis.edu.pl www.elpis.uwb.edu.pl 